\title{
Neodymium isotopes distribution and transport in the central North Pacific deep water
}

\author{
CHEN TianYu, LING HongFei* \& HU Rong \\ State Key Laboratory for Mineral Deposits Research, School of Earth Sciences and Engineering, Nanjing University, Nanjing 210093, China
}

Received January 24, 2011; accepted April 29, 2011

\begin{abstract}
Radiogenic Neodymium (Nd) isotopes in the central North Pacific deep water have been generally interpreted as reflecting Pacific arcs input according to previous studies, while little is known about the specific path and mode of radiogenic Nd from these arcs to deep water. In this study, Nd isotopic data from surface scrapings of $17 \mathrm{Fe}-\mathrm{Mn}$ crusts from the central North Pacific deep water (around $20^{\circ} \mathrm{N}$ ) have been reported. Based on these data together with recently published data on dissolved Nd isotopes in seawater for this region, we propose that radiogenic Nd isotopes in North Pacific Intermediate Water (NPIW 300-800 m) from the western Pacific margin is an important source for the central North Pacific deep water, while the surface water of this area has little influence on dominating deep water $\mathrm{Nd}$ isotopes. Such a view emphasizes the role of vertical mixing and advection of the marginal ocean currents in balancing Nd isotopes in central North Pacific deep water, and helps to understand oceanic Nd cycling. Moreover, the values of $\varepsilon_{\mathrm{Nd}}$ from surface scrapings of $\mathrm{Fe}-\mathrm{Mn}$ crusts are relatively homogenous, with an average value of about -3.4 , which is higher than that of modern seawater $(\sim-3.9)$. This difference over short time scales reflects the quick evolution of Nd isotopes in central North Pacific deep water.
\end{abstract}

central north Pacific deep water, Nd isotopes, Fe-Mn crusts, intermediate water, Nd budget

Citation: $\quad$ Chen T Y, Ling H F, Hu R. Neodymium isotopes distribution and transport in the central North Pacific deep water. Chinese Sci Bull, 2011, 56: 2243-2250, doi: 10.1007/s11434-011-4452-9

Oceanic Neodymium (Nd) isotopic studies (including authigenic ferromanganese deposits), which began in the late 1970s [1], have now became a powerful method to reconstruct modern and past ocean circulation. Compared with other tracers of paleo-oceanic currents (such as $\mathrm{C}$ isotopes and $\mathrm{Cd} / \mathrm{Ca}$ of foraminifera), $\mathrm{Nd}$ isotopes are less affected by factors not directly related to ocean currents (e.g. biological activity) [2], and have thus attracted growing attention from the paleooceanographic community.

Of the global oceans the North Pacific contains the most radiogenic $\mathrm{Nd}$ isotopes [1]. Based on the study of three North Pacific deep water ferromanganese crusts, Ling et al. [3] discovered the discrepancy of $\mathrm{Nd}$ isotopic compositions at different depths, and concluded such discrepancies can be traced back to at least $25 \mathrm{Ma}$. In fact, there were already

*Corresponding author (email: hfling@nju.edu.cn) many Atlantic Nd isotopic data on seawater and ferromanganese crusts, while data on the Pacific were still very scarce, and sample depth information was often missing in the early studies $[1,4]$. In general, the high $\varepsilon_{\mathrm{Nd}}$ value of the Pacific can be interpreted as weathering input from the widely distributed active volcanic arcs around the Pacific, most of which have high $\varepsilon_{\mathrm{Nd}}$ (e.g. [1]). However, the transport path and mode of radiogenic Nd in the North Pacific deep water are still not well understood. Consequently, the interpretations of past $\mathrm{Nd}$ isotopic variations in this area were not very clear. Given the trend of more and more highresolution $\mathrm{Nd}$ isotope studies for tracing the paleo-ocean circulation (e.g. glacial-interglacial) in recent years [5-9], it becomes more important to understand the radiogenic sources of the North Pacific deep water, which will help to reconstruct the North Pacific glacial-interglacial or even millennium-scale circulation changes. 
To further understand the radiogenic $\mathrm{Nd}$ sources in the deep central North Pacific, we report ferromanganese crust $\mathrm{Nd}$ isotope data with different water depths near $20^{\circ} \mathrm{N}$ in this study. Hydrothermal $\mathrm{Nd}$ has an insignificant effect on seawater $[10,11]$. Thus the $\mathrm{Nd}$ isotopes in seawater are mainly controlled by continental inputs (including the islandarc weathering). When terrigenous materials are transported by rivers and dust to the ocean surface, they can release part of their $\mathrm{Nd}$ to the deep water by advection and diffusion [12], so that seawater can acquire a corresponding $\mathrm{Nd}$ isotopic composition. Meanwhile Nd can be absorbed onto and desorbed from particles in the seawater, and then be introduced into the deep water during particle sinking $[13,14]$. The shelf sediment-seawater $\mathrm{Nd}$ isotope exchange can also transfer $\mathrm{Nd}$ to the deep ocean [15-17]. Based on these and the modern ocean current studies and data of this study, we demonstrate that the advective transport of $\mathrm{Nd}$ by North Pacific Intermediate Water is an important source of radiogenic Nd. Furthermore, we also find the quick evolution of $\mathrm{Nd}$ isotope composition of the North Pacific deep water in a short time scale.

\section{Modern oceanography in the North Pacific}

The North Pacific surface currents are schematically shown in Figure 1(a) (the orange solid line and purple dotted line), with the Kuroshio Current being part of this system. On the other hand, in the Subarctic Pacific (north of $40^{\circ} \mathrm{N}$ ), Oyashio is characterized by counterclockwise circulation. High salinity North Pacific Tropical Water (NPTW, $\theta=18-25^{\circ} \mathrm{C}$, $\mathrm{S}=34.8-35.3, \sigma_{\theta}=23.0-25.0$, depth $100-200 \mathrm{~m}$ ) is widely distributed in the North Pacific subsurface depth [25]. Although in the modern North Pacific there are no deep water mass formations, the intermediate water can still have good ventilation [26]. While the intermediate water mainly originates from the Sea of Okhotsk [18-20], there is also sporadic formation in the Gulf of Alaska [27]. North Pacific Intermediate Water (NPIW, $\theta=1.4-6.4^{\circ} \mathrm{C}, \mathrm{S}=33.3-33.4, \sigma_{\theta}=$ 26.6-27.4) is about $300-800 \mathrm{~m}$ deep and circulates clockwise [18-20]. After the major currents at about $40^{\circ} \mathrm{N}$ flow eastward to about $150^{\circ} \mathrm{W}$, they turn southward to about $20^{\circ} \mathrm{N}$, and then there is some return flow to the west. At about $3500 \mathrm{~m}$, the deep ocean currents, mainly from the Upper Circumpolar Deep Water (UCDW), are transported along the Southwest Pacific from the Southern Ocean. Near the equator, the deep ocean currents mainly export to the Philippine Sea, and ultimately form part of the Pacific Deep Water (PDW) (the major path is shown as the dark blue dotted line in Figure 1(a) [21-23]). Water masses deeper than $3500 \mathrm{~m}$ are the northward transport of the Lower Circumpolar Deep Water (LCDW) which is characterized by high salinity and low silica, and is the remnant of the North Atlantic Deep Water (NADW) [24]. The North Pacific deep return flow mainly concentrates on the eastern Pacific basins, whereas the upwelling is mostly located east of $20^{\circ} \mathrm{W}$

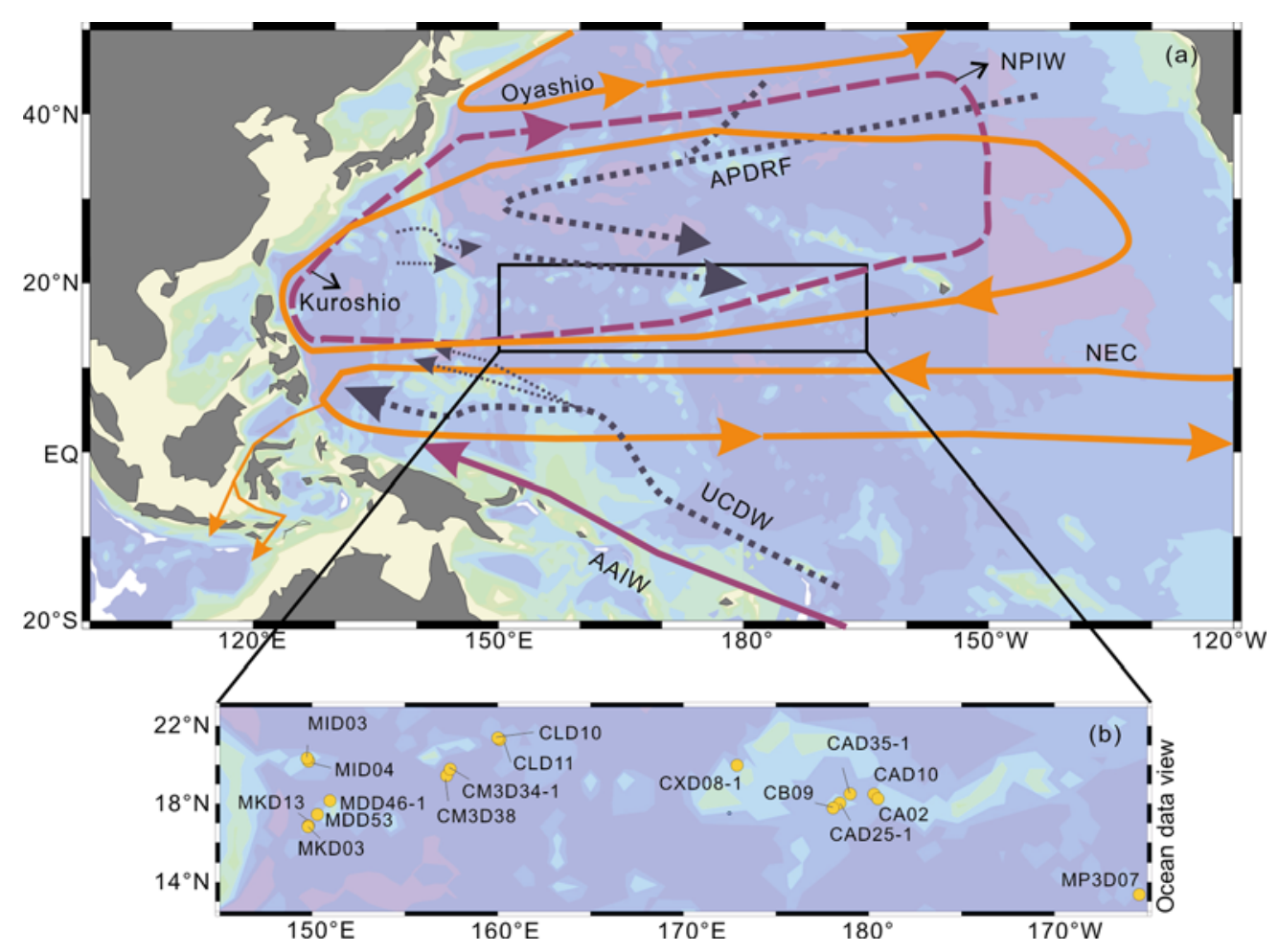

Figure 1 (a) A schematic map showing the major currents of the North Pacific: Surface ( $<200 \mathrm{~m}$, orange solid line); intermediate (200-1500 m, dashed purple line), and deep (deep blue dotted line). The black box indicates the area of this study [18-24]. APDRF, Subarctic Pacific return flow; NEC, North Equatorial current; UCDW, Upper Circumpolar Deep Water; AAIW, Antarctic Intermediate Water; (b) sample location map. 
and north of $40^{\circ} \mathrm{N}$ in the Pacific [24]. More details about present-day North Pacific circulation can be found in [24].

The study area is located in the central North Pacific near $20^{\circ} \mathrm{N}$ (Figure 1). Based on the North Pacific circulation background discussed above, the water mass structure of the study area is illustrated by the traditional Temperature-Salinity diagram (Figure 2). According to Figure 2, we can see that NPTW (about $150 \mathrm{~m}$ ) is characterized by high salinity (about 35.1), while NPIW (500-600 m) is characterized by lower salinity in this area. In contrast, the central North Pacific Deep Water (CNPDW, below $1500 \mathrm{~m}$ ) has a very narrow range of temperature and salinity, which is formed by the Antarctic Bottom Water (AABW) mixed with a small amount of NPIW. It should be noted that, due to partial mixing with the surrounding water masses during transport, the salinity of NPTW in this area is slightly decreased, while the temperature and salinity of NPIW are slightly increased.

\section{Materials and methods}

Ferromanganese crusts in this study were all collected from the central North Pacific seamounts (Figure 1(b)) during the cruises organized by the State Oceanic Administration of China. For Nd isotope analysis, about $10 \mathrm{mg}$ of each sample was gently scraped from the crust surface using a blade. The depth of these crusts can be seen in Table 1. Neodymium isotope measurement was carried out at the State Key Laboratory for Mineral Deposits Research at Nanjing University, using $\mathrm{LN}$ resin and $\mathrm{HCl}$ leaching for the chemical separation of $\mathrm{Nd}$. Neodymium measurements were performed with a Finnigan Triton thermal ionization mass spectrometer (TIMS). ${ }^{143} \mathrm{Nd} /{ }^{144} \mathrm{Nd}$ ratios were normalized to

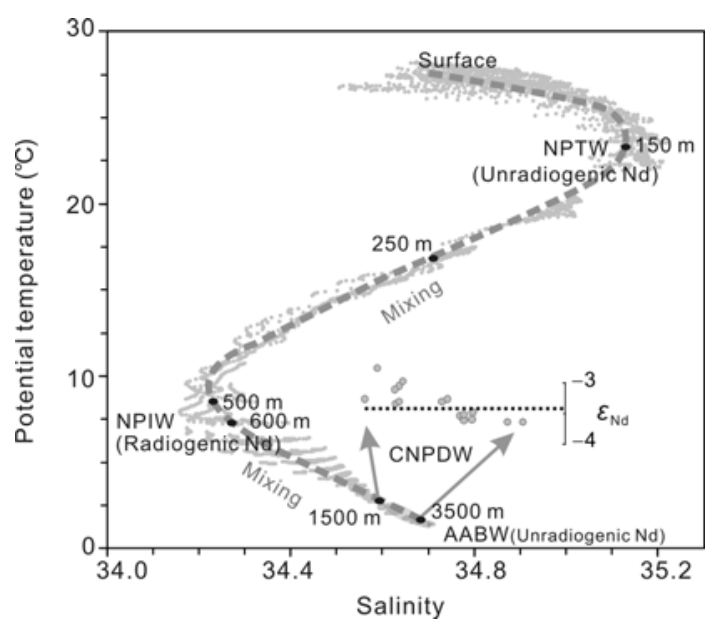

Figure 2 The temperature-salinity distribution of seawater in the study area (data source: World Ocean Atlas 2005. http://odv.awi.de/en/data/ ocean/world_ocean_atlas_2005/). The circles represent $\varepsilon_{\mathrm{Nd}}$ distribution of the crust surface samples. As shown by the gray arrows, the depth of samples increases from 1500 to $3500 \mathrm{~m}$ (left to right).
Table $1 \mathrm{Nd}$ isotopic compositions for the crust surface samples ${ }^{\text {a) }}$

\begin{tabular}{lccc}
\hline \multicolumn{1}{c}{ Sample } & Depth $(\mathrm{m})$ & ${ }^{143} \mathrm{Nd} /{ }^{144} \mathrm{Nd}($ surface $)$ & $\varepsilon_{\mathrm{Nd}}$ \\
\hline CA02 & 3285 & $0.512452 \pm 4$ & -3.6 \\
duplicate & & $0.512453 \pm 2$ & -3.6 \\
CB09 & 3474 & $0.512452 \pm 2$ & -3.6 \\
duplicate & & $0.512454 \pm 4$ & -3.6 \\
CM3D34-1 & 2748 & $0.512454 \pm 1$ & -3.6 \\
duplicate & 2850 & $0.512460 \pm 2$ & -3.5 \\
CLD10 & 2700 & $0.512454 \pm 27$ & -3.6 \\
MDD53 & 2860 & $0.512457 \pm 2$ & -3.5 \\
MP3D07 & 1530 & $0.512460 \pm 5$ & -3.5 \\
MKD13 & $0.512471 \pm 2$ & -3.2 \\
CAD35-1 & 2000 & $0.512486 \pm 1$ & -3.0 \\
MID03 & 1680 & $0.512497 \pm 3$ & -2.8 \\
MKD03 & 1900 & $0.512479 \pm 1$ & -3.1 \\
CXD08-1 & 1910 & $0.512467 \pm 2$ & -3.3 \\
MID04 & 1950 & $0.512469 \pm 3$ & -3.3 \\
CAD10 & 2480 & $0.512469 \pm 1$ & -3.3 \\
CAD25-1 & 2750 & $0.512453 \pm 2$ & -3.6 \\
CLD11 & 2750 & $0.512458 \pm 1$ & -3.5 \\
CM3D38 & 2548 & $0.512471 \pm 1$ & -3.2 \\
MDD46-1 & 1950 & $0.512482 \pm 3$ & -3.0 \\
\hline
\end{tabular}

a) Longitudes and latitudes of these samples are available upon request.

${ }^{146} \mathrm{Nd} /{ }^{144} \mathrm{Nd}=0.7219$ to correct for the instrumental mass bias during measuring. Repeated analyses of the $\mathrm{Nd}$ standard JNdi-1 yielded $0.512121 \pm 2(2 \sigma$ external standard deviation, $n=15)$.

\section{Results and discussion}

\subsection{Results for Nd isotopic compositions of surface samples}

The Nd isotopic compositions of these samples are listed in Table 1. In general, the ferromanganese samples should represent the average $\mathrm{Nd}$ isotopic composition of ambient seawater over a certain period of time. For the surface samples, the Nd isotopes of the central North Pacific deep water were integrated through the late Quaternary. It can be seen from Figure 2 that the $\varepsilon_{\mathrm{Nd}}$ values are relatively uniform in late Quaternary central North Pacific Deep Water, with a maximum value of -2.8 , a minimum value of -3.6 , and an average of about -3.4 . Nevertheless, $\mathrm{Nd}$ isotopes still became slightly more unradiogenic with increasing depth (Figure 3). In the upper part of deep water (e.g. $<2500 \mathrm{~m}$ ), greater variations of $\varepsilon_{\mathrm{Nd}}$ at a similar depth are found than in the lower part of deep water (Figures 3 and 4). However, there is almost no horizontal $\varepsilon_{\mathrm{Nd}}$ gradient.

\subsection{Distribution and transport of radiogenic $\mathrm{Nd}$ to deep water}

As shown in Figure 3, an obvious feature of the distribution 


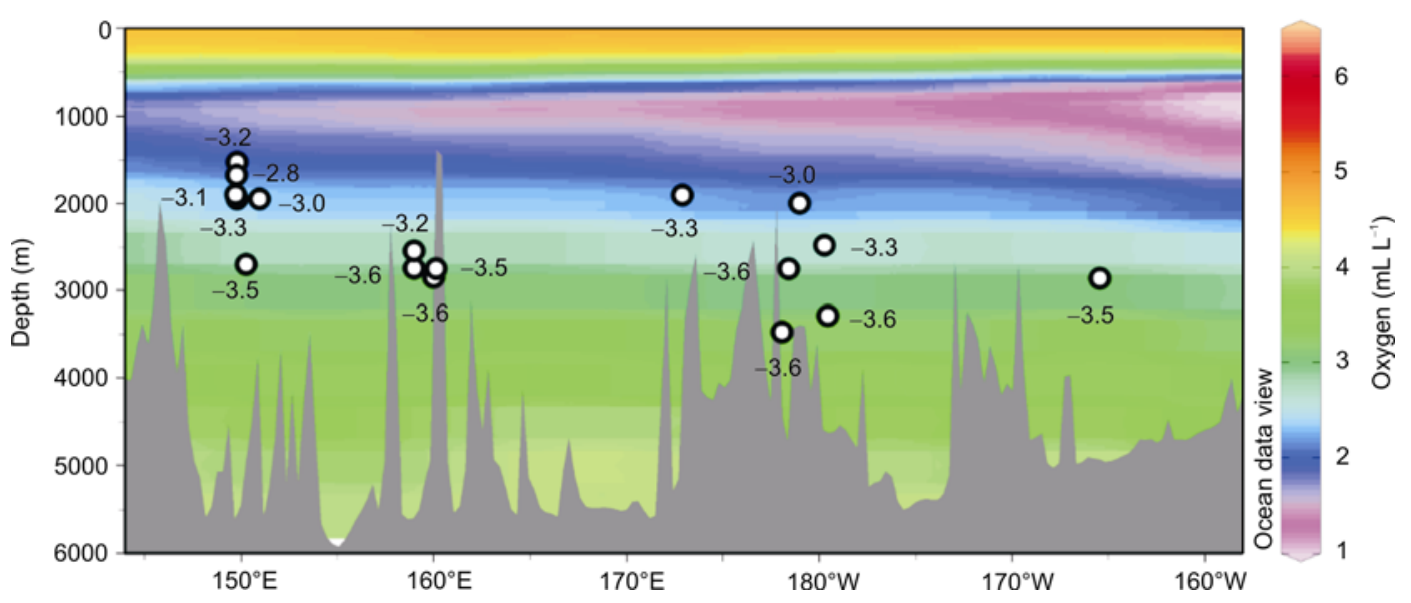

Figure $3 \varepsilon_{\mathrm{Nd}}$ distribution of the crust surface samples along the $20^{\circ} \mathrm{N}$ profile. It is noted $\mathrm{Nd}$ isotopes show almost no horizontal gradient. The filled color represents the contents of $\mathrm{O}_{2}\left(\mathrm{~mL} \mathrm{~L}^{-1}\right)$. One can easily see that the southern component water is characterized by higher $\mathrm{O}_{2}$ content at the bottom (near $\left.170^{\circ} \mathrm{E}\right)$. The figure was generated using Ocean data view. Data source for oxygen content: World Ocean Atlas (2009) (odv.awi.de).

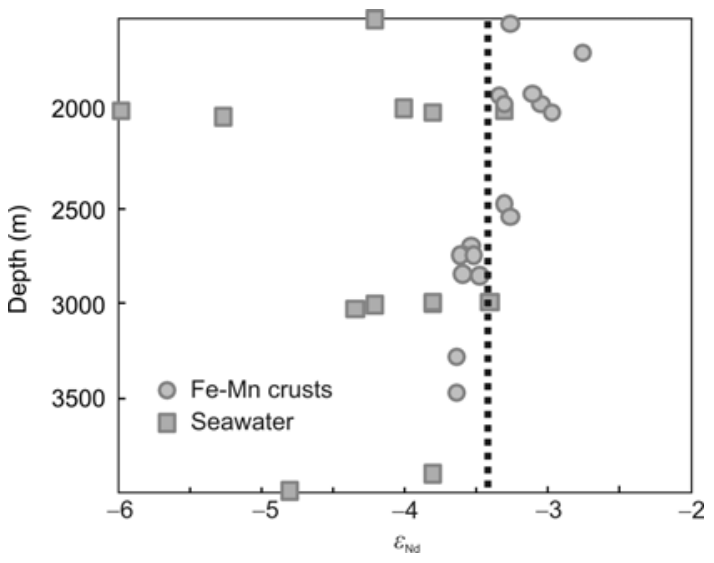

Figure 4 A comparison of $\varepsilon_{\mathrm{Nd}}$ between modern seawater [28,29] and crust surface samples.

of deep water $\varepsilon_{\mathrm{Nd}}$ values is their homogeneity at a similar depth. For example, at about $3000 \mathrm{~m}$, two samples (MDD53, MP3D07) which are separated by a distance of nearly 5000 $\mathrm{km}$ at about $165^{\circ} \mathrm{W}$ and $150^{\circ} \mathrm{E}$, show $\varepsilon_{\mathrm{Nd}}$ values of -3.5 to -3.6 , clearly more radiogenic than in the Southern Ocean $\left(\varepsilon_{\mathrm{Nd}}<-5\right)$. The issue is where the sources of the radiogenic $\mathrm{Nd}$ are, and how the central North Pacific deep water, which has an average $\varepsilon_{\mathrm{Nd}}$ of about -3.5 but comes from the Southern Ocean $\left(\varepsilon_{\mathrm{Nd}}<-5\right)$, acquires its radiogenic signature.

Previous views about the potential sources and input mechanisms of radiogenic Nd isotopes for the central North Pacific deep water include: (a) physical convection-diffusion taking surface $\mathrm{Nd}$ to the deep water [12]; (b) vertical sinking of particles through adsorption and desorption drawing the surface $\mathrm{Nd}(<200 \mathrm{~m})$ down into the deep sea [30]; (c) dissolution of highly radiogenic volcanic ash and glass in the seawater adding extra radiogenic $\mathrm{Nd}$ [31]; and (d) Nd being released from the continental shelf and seafloor sediments into the deep Pacific water [32].
To simulate $\mathrm{Nd}$ isotope distribution in the seawater, Jones et al. [12] set $\mathrm{Nd}$ isotopic compositions of the surface ocean as boundary conditions, and assumed $\mathrm{Nd}$ was a fully conservative element. For the North Atlantic, the simulation agrees well with the observed distribution of $\mathrm{Nd}$ isotopes, but for the North Pacific deep water the simulated $\varepsilon_{\mathrm{Nd}}$ values are lower than the observed values. Therefore, the $\mathrm{Nd}$ isotopes from the surface ocean through diffusion and convection are not enough to account for the deep radiogenic feature. Siddall et al. [30] used Nd isotopes and concentration at the ocean surface as boundary conditions, in combination with the reversible scavenging model, to explain the global seawater $\mathrm{Nd}$ isotopes and their concentrations. The simulation results for the North Pacific deep water are much closer to the observed values compared with the results of Jones et al. [12]. This indicates that reversible scavenging is important in taking the upper North Pacific radiogenic Nd into deep water, but there are still some unresolved issues: (a) Siddall et al. [30] did not effectively simulate either the observed widespread un-radiogenic signature in the North Pacific subsurface water [28] ( 100-300 m) or the gradually increasing value of $\varepsilon_{\mathrm{Nd}}$ downwards (to about $1000 \mathrm{~m}$ ). This indicates that $\mathrm{Nd}$ from the North Pacific surface waters alone is unable to generate the observed distribution of radiogenic $\mathrm{Nd}$ in deep water. (b) Most of the North Pacific radiogenic signature of $\mathrm{Nd}$ (i.e. $\varepsilon_{\mathrm{Nd}}$ higher than -4 ) is somewhat underestimated in the modeling. To explain such discrepancy, Siddall et al. [30] point out that since the modeled surface boundary conditions are too simple, some of the radiogenic sources with high $\varepsilon_{\mathrm{Nd}}$ are not included in the model simulation (e.g. near the Hawaiian islands). However, even if some surface areas with high $\varepsilon_{\mathrm{Nd}}$ have not been considered in the boundary conditions [30], these local surface regions are still unlikely to contribute much to the deep radiogenic $\mathrm{Nd}$ isotopes. For example, the Hawaii Island chain, which could provide much radiogenic $\mathrm{Nd}$ to the surface 
water, has almost no effect on deep water $\mathrm{Nd}$ isotopes [28]. Thus there is no reliable evidence to support an argument that the central North Pacific surface water provides enough radiogenic $\mathrm{Nd}$ to the deep water.

It is still difficult to estimate the dissolved flux of highly radiogenic volcanic ash and glass in the seawater. Previous studies have shown that most of the leachable components of volcanic ash are released into the seawater during the initial stages of dissolution, and then dissolution rate decreases rapidly. Consequently, the dissolution of ash and volcanic glass should take place mainly on the ocean surface [33]. As mentioned above, the ocean surface is unlikely to fully explain the North Pacific deep water radiogenic $\mathrm{Nd}$ isotope distribution. Thus we consider that dissolution of ash and volcanic glass in seawater is not an important source of deep water radiogenic $\mathrm{Nd}$.

One possible explanation is that the radiogenic $\mathrm{Nd}$ of the central North Pacific deep water comes from re-dissolution of deep shelf sediments (for example, 0-3000 m [32]), and is advected by deep currents to the central North Pacific deep water which is mixed with un-radiogenic southern component water. In this case, the radiogenic Nd is characterized by pervasive input from the continental shelf. For example, Arsouze et al. [32] assume that ocean sediment at a depth of less than $3000 \mathrm{~m}$ would export $\mathrm{Nd}$ to the ocean. However, there are still questions remaining about this model which assumes the dissolution of deep sea sediments as the most important source of radiogenic $\mathrm{Nd}$ for the central North Pacific deep water: (a) the role of shelf sediment at more than $1000 \mathrm{~m}$ is not yet understood, i.e. it is still unclear whether this zone is the source or sink for marine $\mathrm{Nd}$, or has no noticeable influence on the seawater. Based on the $\mathrm{Nd}$ isotopes at the station near Hawaii, Amakawa et al. [28] found that although the ocean surface may be influenced by the $\mathrm{Nd}$ exchange of volcanic rocks in Hawaii, the deep water does not seem to be affected. (b) Arsouze et al. [32] used a biogeochemical ocean circulation model to simulate the $\mathrm{Nd}$ distribution in seawater. They used a pre-set shelf sediment flux as the boundary condition and found that the shelf sediments might account for $90 \%$ of the Nd input. Although the $\mathrm{Nd}$ isotopic compositions can be reproduced well, the concentrations of $\mathrm{Nd}$ are not satisfactorily simulated.

We suggest that the radiogenic NPIW [34] may be an important source for deep water $\mathrm{Nd}$ isotope distribution. With a reversible scavenging model [30], the $\mathrm{Nd}$ isotope distribution of the central North Pacific deep water can be readily explained as follows: NPIW transfers its Nd from the Northwest Pacific to the central North Pacific, and Nd is then brought down to the deep water through reversible adsorption-desorption of particulates. The $\mathrm{Nd}$ isotopic compositions of NPIW are not uniform $\left(\varepsilon_{\mathrm{Nd}}=-5.3\right.$ to -3.1 , with an average of -3.6 [28]), due to the mixing of many different water masses with different $\mathrm{Nd}$ isotopic compositions [34], such as the Kuroshio ( -3.9 to -5.6$)$, Oyashio $(-1.6$ to -2.7$)$ and the Tsugaru warm currents $[19,35]$, dur- ing the formation process of the NPIW in the Northwest Pacific. However, the Nd isotopes of NPIW become more uniform during the advection process, which is consistent with the observation that the $\mathrm{Nd}$ isotopes of surface samples of crusts in the lower deeper water (e.g. $<2500 \mathrm{~m}$ ) are more uniform than in the upper deep water. Although it is still difficult to accurately calculate the flux of $\mathrm{Nd}$ carried by NPIW from the Northwest marginal Pacific, the following first order estimate shows that such flux is considerable: The estimated flux of newly formed NPIW is about $6 \times 10^{6}$ $\mathrm{m}^{3} / \mathrm{s}$ in the mixed water region near Japan (Talley et al. [19]). If all the newly formed NPIW transport into the central North Pacific, with an Nd concentration of $\sim 20 \mathrm{pmol} / \mathrm{ka}$ [28], the Nd flux carried by NPIW would then be $5.6 \times 10^{8}$ $\mathrm{g} / \mathrm{a}$, which is about twice the current global riverine flux $\left(2.6 \times 10^{8} \mathrm{~g}(\mathrm{Nd}) / \mathrm{a}[32]\right)$. Therefore, we suggest that NPIW is an important source for $\mathrm{Nd}$ in deep water.

We can further calculate the $\mathrm{Nd}$ isotope composition of the central North Pacific deep water through a simple box model approach. As shown in Figure 5, if we consider only the contribution of Subarctic Pacific (north of $40^{\circ} \mathrm{N}$ ) return flow, southern component water, and NPIW, without considering the contribution from surface and deep-sea volcanic ash dissolution, then at steady state, the $\mathrm{Nd}$ isotopic composition can be calculated as $\varepsilon_{\mathrm{CNPDW}}=\left(F_{\mathrm{sw}} \times \varepsilon_{\mathrm{sw}}+F_{\mathrm{rf}} \times\right.$ $\left.\varepsilon_{\text {rf }}+F_{\text {NPIW }} \times \varepsilon_{\text {NPIW }}\right) /\left(F_{\text {sw }}+F_{\text {rf }}+F_{\text {NPIW }}\right)$. The $\varepsilon_{\text {Nd }}$ value obtained is -4.1 , which is close to the observed $\varepsilon_{\mathrm{Nd}}$ average value ( -4.0) of North Pacific deep water [12]. This further quantitatively supports the assumption that other radiogenic sources of Nd appear to be unimportant, while the Subarctic Pacific return flow and NPIW are sufficient to explain the radiogenic $\mathrm{Nd}$ isotope content for central North Pacific deep water.

Physical mixing can introduce some $\mathrm{Nd}$ into the deep water. However, according to the temperature-salinity diagram (Figure 2), it is clear the central North Pacific deep water mainly inherits the characteristics of the southern component water, whereas NPIW has little effect on modifying its temperature and salinity. Specifically, the temperature and salinity of central North Pacific deep water are very close to the AABW but far from the NPIW along the mixing line. Because the southern component water enters this area with an $\varepsilon_{\mathrm{Nd}}$ value of about -5 [28], while the $\varepsilon_{\mathrm{Nd}}$ of the crust surface samples vary from -3 to -4 , with a -3.4 average and a slightly increase in $\varepsilon_{\mathrm{Nd}}$ values downwards (Figure 4), the deep water should have received significant contributions of radiogenic Nd from other sources (NPIW). Therefore, $\mathrm{Nd}$ in the North Pacific deep water cannot be conservative. In fact, reversible scavenging of dissolved $\mathrm{Nd}$ may be the main mechanism that removes $\mathrm{Nd}$ from seawater (e.g. $[13,14,37])$. This is demonstrated by the fact that the concentration of seawater $\mathrm{Nd}$ increases with depth. For example, in the North Pacific, Nd concentrations increase from $\sim 5 \mathrm{pmol} / \mathrm{kg}$ in the surface water to $\sim 30 \mathrm{pmol} / \mathrm{kg}$ in deep water. This concentration profile supports the theory 


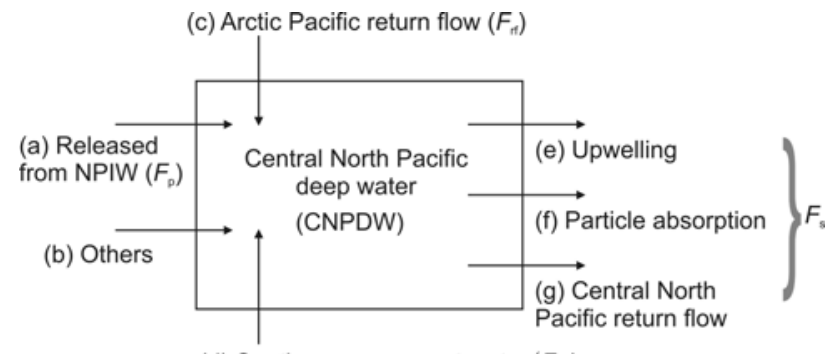

(d) Southern component water $\left(F_{\mathrm{sw}}\right)$

Figure 5 Illustration of the $\mathrm{Nd}$ budget (south of $40^{\circ} \mathrm{N}$ ) in central North Pacific deep water (1500-3500 m). (a) Nd released from the sinking particles of the NPIW should contain the surface ocean flux. Such a surface flux is categorized in (b). Here only the Nd flux from the NPIW source area is taken into account. $F_{\mathrm{p}}=5.6 \times 10^{8} \mathrm{~g} / \mathrm{a}$ (see calculation in the text); Nd isotopic composition: $\varepsilon_{\mathrm{p}}=-3.6$ [28]. (b) Dissolution of dust, volcanic ash, and input from central North Pacific surface water are included. (c) Subarctic North Pacific deep water return flux is about $4 \times 10^{6} \mathrm{~m}^{3} / \mathrm{s}$ [24]. Nd concentration was set to be the same as the central North Pacific deep water $(\sim 30$ $\mathrm{pmol} / \mathrm{kg}$ [28]). Thus the Nd flux $F_{\mathrm{rf}}$ is approximately $5.6 \times 10^{8} \mathrm{~g} / \mathrm{a}$. Nd isotopic composition $\left(\varepsilon_{\mathrm{rf}}\right)$ of crust surface samples of this area is $\sim-2.1$ [36], which may be higher than that of the present ocean levels. Based on data from the seawater of the subarctic Pacific station [28], we choose $\varepsilon_{\mathrm{rf}}$ as -3.0. (d) The modified southern component water flux to the central North Pacific is about $8 \times 10^{6} \mathrm{~m}^{3} / \mathrm{s}$ [36]. Our southern component water of interest is actually UCDW $(<3500 \mathrm{~m})$, which flows along the western Pacific [24]. Therefore, we set the concentration of $\mathrm{Nd}$ in the southern component water to be the same as the central North Pacific deep water ( $30 \mathrm{pmol} / \mathrm{kg}[28])$. Then the Nd flux $F_{\text {rf }}$ is about $11 \times 10^{8} \mathrm{~g} / \mathrm{a}$. Nd isotopic composition $\varepsilon_{\mathrm{sw}}$ is set to be -5.0 (seawater: -4 to -5 [28], crust surface samples $(4800 \mathrm{~m})$ are about -4.6 [3]). (e), (f) and (g) They are considered as the sinks of the North Pacific deep water Nd. In steady state, we can suppose that their Nd isotopic compositions are the same as the central North Pacific deep water $(-4.0,[12])$, and that the total output flux is equal to the total input $\left(F_{\mathrm{s}}=F_{\mathrm{rf}}\right.$ $\left.+F_{\mathrm{bw}}+F_{\mathrm{p}}\right)$.

that marine $\mathrm{Nd}$ is strongly linked to biogeochemical cycles [14]. Particles formed in the surface water would sink and be re-mineralized in the deep water, during which most of the adsorbed $\mathrm{Nd}$ would be released to or exchanged within the deep water. Oka et al. [14] studied the distribution of rare earth elements in the North Pacific and proposed that only when these elements (including $\mathrm{Nd}$ ) have a reversible adsorption and desorption behavior on the particles, can their concentration profiles be correctly reproduced by simulation. In summary, we suggest that Nd from NPIW is introduced into deep water mainly through reversible scavenging.

Another question that needs to be further discussed is why the Nd isotope signal of NPIW remains stable during its transport in the North Pacific and is not affected by $\mathrm{Nd}$ addition from the overlying water. Since the surface water is mainly controlled by riverine and dust input, the flux from the marginal to oligotrophic open ocean surface would be largely limited because a large part of $\mathrm{Nd}$ would be absorbed by strong biological activity in the shelf area. The downward flux from the North Pacific gyre surface water would then be small. Moreover, dust directly supplying the central North Pacific (mainly from western China and central Asia $[38,39])$ has very un-radiogenic $\mathrm{Nd}\left(\varepsilon_{\mathrm{Nd}}\right.$ around
-10 [39]), and obviously cannot be the source for the radiogenic $\mathrm{Nd}$ in deep water. Our calculations above show that Nd from NPIW could be twice that of the global riverine input. Therefore, as a rapid ventilating water mass, NPIW [26] could carry enough Nd from its source region in the Northwest Pacific near Japan to the central North Pacific without being significantly modified by $\mathrm{Nd}$ desorbed from the particles sinking from the surface.

\subsection{Implications for marine Nd cycling}

The above discussion shows that NPIW is a major source that transports $\mathrm{Nd}$ to the deep central North Pacific. Together with the Subarctic Pacific return flow, it could account for the $\mathrm{Nd}$ isotopic distribution in the central North Pacific deep water. This improves our previous understanding about the path and transport of $\mathrm{Nd}$ in the central North Pacific, where the traditional view is that central North Pacific surface waters may significantly influence the $\mathrm{Nd}$ isotopes of deep water [30]. NPIW forms in the western North Pacific margin, and its own $\mathrm{Nd}$ sources may include rivers, dust and shelf sediment-water exchange. Accordingly, it may not be necessary to introduce a widely distributed deep sediment-seawater exchange mechanism [32] for the central North Pacific deep water Nd. However, as noted above, the amount of Nd carried by NPIW has to be further constrained quantitatively, and attention should be paid to such an input mechanism in future studies. We suggest that further modeling of $\mathrm{Nd}$ distribution in North Pacific Deep Water could try to incorporate $\mathrm{Nd}$ isotopes of NPIW as the boundary condition.

\subsection{Implications of the difference in $\mathrm{Nd}$ isotopes between crust surfaces and modern/Cenozoic records}

As shown in Figure 3 , the $\varepsilon_{\mathrm{Nd}}$ of crust surface samples slowly increases as depth reduces from 3500 to $1500 \mathrm{~m}$, which is consistent with the present pattern of the vertical distribution of $\mathrm{Nd}$ isotopes in the North Pacific. The overall variation of $\varepsilon_{\mathrm{Nd}}$ values is $\sim 0.6$ units, however, much less variation ( 0.3 units) is found near $180^{\circ}$ at below $2000 \mathrm{~m}$. However, Ling et al. [40] reported larger than 0.6 units difference in $\mathrm{Nd}$ isotope composition between crusts $\mathrm{CB} 12$ $(\sim 2400 \mathrm{~m})$ and CJ01 $(\sim 3100 \mathrm{~m})$ in the same area before the Quaternary. Our recently obtained Nd isotopic records from two crust profiles (unpublished data) near $150^{\circ} \mathrm{E}$ (MKD13, MDD53, see Figure 1(b)) also indicate that $\varepsilon_{\mathrm{Nd}}$ differences could be larger than 1 unit in the early Pliocene deep water. This suggests that vertical homogenization of $\mathrm{Nd}$ isotopes may have been strengthened in the central North Pacific deep water in the near past.

It is also noteworthy that $\mathrm{Nd}$ isotopes of the crust surface samples (average value of -3.4 in this study) are apparently more radiogenic than those for the present ambient seawater $(-3.9$ [28]). Nd residence time in the deep sea is about several 
hundreds of years [41], so the modern deep water $\mathrm{Nd}$ isotopes only reflect the integration of a few centuries. In contrast, the ferromanganese crusts grow very slowly, usually only 1-3 mm/Ma in the North Pacific deep water (e.g. [42]). Although the composition of ferromanganese crusts could well reflect the influence of orbital-scale changes in ocean currents and climate (see the in situ high resolution studies of Han et al. on ferromanganese nodules [43] and crusts [44]), the data obtained in this study represent an integration of $\mathrm{Nd}$ isotopes over a relatively longer time (but still less than $1 \mathrm{Ma}$, because the sampling depth is less than $1 \mathrm{~mm}$ ) [31]. Therefore, apart from the previously discovered long-term $\mathrm{Nd}$ isotopic changes on a million year scale $[3,40]$, it is very likely that $\mathrm{Nd}$ isotopes also vary over a very short time scale (within the last $1 \mathrm{Ma}$ ) in the central North Pacific. Because the samples may well contain an integration of several glacial-interglacial cycles [31], one possible reason for the discrepancy between seawater and crust surfaces is that the North Pacific deep water in glacial stages is more radiogenic than the present interglacial times. It is also possible that $\mathrm{Nd}$ isotopic variations in the North Pacific deep water may not be cyclic, so the exact cause of such inconsistency remains to be clearly understood. Up to now, no $\mathrm{Nd}$ isotope data have been published over orbital or millennium time scales in the studied area, which certainly deserves future research.

\section{Conclusions}

In this study, the Nd isotope compositions of crusts surface samples from the central North Pacific deep water have been reported. In combination with published $\mathrm{Nd}$ isotope data of modern seawater, we draw the following conclusions:

(1) The North Pacific Intermediate Water (NPIW) formed in the Northwest Pacific carries radiogenic $\mathrm{Nd}$ from the source area to the central North Pacific. This is probably an important way for the central North Pacific deep water to acquire their radiogenic $\mathrm{Nd}$ isotopes, while the central North Pacific surface water may have little influence on the deep water $\mathrm{Nd}$ isotopes.

(2) The marginal Nd cycling and input to the deep water may be important in understanding the oceanic Nd budget, which deserves more attention in future studies, especially in modeling studies.

(3) The crust surface samples have more radiogenic $\mathrm{Nd}$ isotopes than ambient modern seawater, indicating that $\mathrm{Nd}$ isotopic compositions are not stable over relatively short time scales in the central North Pacific.

The authors would like to thank the editors and two anonymous reviewers for their constructive comments. The authors are also grateful to $\mathrm{Pu}$ Wei for her laboratory assistance. This work was supported by the Chinese Association for Research of Oceanic Mineral Resources (DY-115-01-2-2) and the Program of the Ministry of Education of China.
1 Piepgras D J, Wasserburg G J, Dasch E J. Isotopic composition of Nd in different ocean masses. Earth Planet Sci Lett, 1979, 45: 223-236

2 Frank M. Radiogenic isotopes: Tracers of past ocean circulation and erosional input. Rev Geophys, 2002, 40, doi: 10.1029/2000RG000094

3 Ling $\mathrm{H} \mathrm{F}$, Burton K W, ONions R K, et al. Evolution of $\mathrm{Nd}$ and $\mathrm{Pb}$ isotopes in Central Pacific seawater from ferromanganese crusts. Earth Planet Sci Lett, 1997, 146: 1-12

4 O'nions $\mathrm{R}$, Carter $\mathrm{S}$, Cohen $\mathrm{R}$, et al. $\mathrm{Pb}, \mathrm{Nd}$ and $\mathrm{Sr}$ isotopes in oceanic ferromanganese deposits and ocean floor basalts. Nature, 1978, 273: 435-438

5 Gutjahr M, Frank M, Stirling $\mathrm{C} \mathrm{H}$, et al. Tracing the $\mathrm{Nd}$ isotope evolution of North Atlantic deep and intermediate waters in the Western North Atlantic since the Last Glacial Maximum from Blake Ridge sediments. Earth Planet Sci Lett, 2008, 266: 61-77

6 Piotrowski A M, Goldstein S L, Hemming S R, et al. Temporal relationships of carbon cycling and ocean circulation at glacial boundaries, Science, 2005, 307: 1933-1938

7 Robinson L F, van de Flierdt T. Southern Ocean evidence for reduced export of North Atlantic Deep Water during Heinrich event 1. Geology, 2009, 37: 195-198

8 Herguera J C, Herbert T, Kashgarian M, et al. Intermediate and deep water mass distribution in the Pacific during the Last Glacial Maximum inferred from oxygen and carbon stable isotopes. Quat Sci Rev, 2010, 29: 1228-1245

9 Horikawa K, Asahara Y, Yamamoto K, et al. Intermediate water formation in the Bering Sea during glacial periods: Evidence from neodymium isotope ratios. Geology, 2010, 38: 435-438

10 Bertram C J, Elderfield H. The geochemical balance of the RareEarth Elements and Neodymium isotopes in the oceans. Geochim Cosmochim Acta, 1993, 57: 1957-1986

11 German C R, Klinkhammer G P, Edmond J M, et al. Hydrothermal scavenging of rare-earth elements in the ocean. Nature, 1990, 345: 516-518

12 Jones K M, Khatiwala S P, Goldstein S L, et al. Modeling the distribution of $\mathrm{Nd}$ isotopes in the oceans using an ocean general circulation model. Earth Planet Sci Lett, 2008, 272: 610-619

13 Jeandel C, Bishop J K, Zindler A. Exchange of Neodymium and its isotopes between seawater and small and large particles in the Sargasso Sea. Geochim Cosmochim Acta, 1995, 59: 535-547

14 Oka A, Hasumi H, Obata H, et al. Study on vertical profiles of rare earth elements by using an ocean general circulation model. Glob Biogeochem Cycle, 2009, 23, doi: 10.1029/2008gb003353

15 Lacan F, Jeandel C. Tracing Papua New Guinea imprint on the central Equatorial Pacific Ocean using neodymium isotopic compositions and rare earth element patterns. Earth Planet Sci Lett, 2001, 186: 497-512

16 Lacan F, Jeandel C. Neodymium isotopes as a new tool for quantifying exchange fluxes at the continent-ocean interface. Earth Planet Sci Lett, 2005, 232: 245-257

17 Lacan F, Jeandel C. Acquisition of the neodymium isotopic composition of the North Atlantic Deep Water. Geochem Geophys Geosyst, 2005, 6, doi: 10.1029/2005gc000956

18 Miyao T, Ishikawa K. Formation, distribution and volume transport of the north pacific intermediate water studied by repeat hydrographic observations. J Oceanogr, 2003, 59: 905-919

19 Talley L D, Nagata Y, Fujimura M, et al. North Pacific Intermediate Water in the Kuroshio Oyashio mixed water region. J Phys Oceanogr, 1995, 25: 475-501

20 You Y Z. The pathway and circulation of North Pacific Intermediate Water. Geophys Res Lett, 2003, 30, doi: 10.1029/2003g1018561

21 Kawabe M, Fujio S, Yanagimoto D. Deep-water circulation at low latitudes in the western North Pacific. Deep-Sea Res Part I, 2003, 50: 631-656

22 Kawabe M, Fujio S, Yanagimoto D, et al. Water masses and currents of deep circulation southwest of the Shatsky Rise in the western North Pacific. Deep-Sea Res Part I, 2009, 56: 1675-1687

23 Kawabe M, Yanagimoto D, Kitagawa S, et al. Variations of the deep western boundary current in Wake Island Passage, Deep-Sea Res Part I, 2005, 52: 1121-1137 
24 Kawabe M, Fujio S. Pacific Ocean Circulation based on observation, J Oceanogr, 2010, 66: 389-403

25 Suga T, Kato A, Hanawa K. North Pacific Tropical Water: Its climatology and temporal changes associated with the climate regime shift in the 1970s. Prog Oceanogr, 2000, 47: 223-256

26 Warner M J, Bullister J L, Wisegarver D P, et al. Basin-wide distributions of chlorofluorocarbons CFC-11 and CFC-12 in the North Pacific: 1985-1989. J Geophys Res-Oceans, 1996, 101: 20525-20542

27 Van Scoy K, Druffnel E. Ventilation and transport of thermocline and intermediate waters in the northeast Pacific during recent El Niños. J Geophys Res, 1993, 98, doi: 10.1029/93JC01797

28 Amakawa H, Sasaki K, Ebihara M. Nd isotopic composition in the central North Pacific. Geochim Cosmochim Acta, 2009, 73: 47054719

29 Piepgras D J, Jacobsen S B. The isotopic composition of Neodymium in the North Pacific. Geochim Cosmochim Acta, 1988, 52: 1373-1381

30 Siddall M, Khatiwala S, van de Flierdt T, et al. Towards explaining the Nd paradox using reversible scavenging in an ocean general circulation model. Earth Planet Sci Lett, 2008, 274: 448-461

31 Albarede F, Goldstein S L. World map of Nd isotopes in sea-floor ferromanganese deposits. Geology, 1992, 20: 761-763

32 Arsouze T, Dutay J C, Lacan F, et al. Reconstructing the Nd oceanic cycle using a coupled dynamical-biogeochemical model. Biogeosciences, 2009, 6: 2829-2846

33 Frogner P, Gislason S R, Oskarsson N. Fertilizing potential of volcanic ash in ocean surface water. Geology, 2001, 29: 487-490

34 Amakawa H, Nozaki Y, Alibo D S, et al. Neodymium isotopic variations in Northwest Pacific waters. Geochim Cosmochim Acta, 2004, 68: 715-727

35 Talley L D. Distribution and formation of North Pacific Intermediate
Water. J Phys Oceanogr, 1993, 23: 517-537

36 van de Flierdt T, Frank M, Lee D C, et al. New constraints on the sources and behavior of neodymium and hafnium in seawater from Pacific Ocean ferromanganese crusts. Geochim Cosmochim Acta, 2004, 68: 3827-3843

37 Nozaki Y. Rare earth elements and their isotopes. Encyclopedia Ocean Sci, 2001, 4: 2354-2366

38 Weber E T, Owen R M, Dickens G R, et al. Quantitative resolution of eolian continental crustal material and volcanic detritus in North Pacific surface sediment. Paleoceanography, 1996, 11: 115-127

39 Jones C E, Halliday A N, Rea D K, et al. Neodymium isotopic variations in North Pacific modern silicate sediment and the insignificance of detrital REE contributions to seawater. Earth Planet Sci Lett, 1994, 127: $55-66$

40 Ling H F, Jiang S Y, Frank M, et al. Differing controls over the Cenozoic $\mathrm{Pb}$ and $\mathrm{Nd}$ isotope evolution of deepwater in the central North Pacific Ocean. Earth Planet Sci Lett, 2005, 232: 345-361

41 Tachikawa K, Athias V, Jeandel C. Neodymium budget in the modern ocean and paleo-oceanographic implications. J Geophys Res-Oceans, 2003, 108, doi: 10.1029/1999jc000285

42 Frank M, O'Nions R K, Hein J R, et al. $60 \mathrm{Myr}$ records of major elements and $\mathrm{Pb}-\mathrm{Nd}$ isotopes from hydrogenous ferromanganese crusts: Reconstruction of seawater paleochemistry. Geochim Cosmochim Acta, 1999, 63: 1689-1708

43 Han X Q, Jin X L, Yang S F, et al. Rhythmic growth of Pacific ferromanganese nodules and their Milankovitch climatic origin. Earth Planet Sci Lett, 2003, 211: 143-157

44 Han X Q, Qiu Z Y, Ma W L, et al. High-resolution dating of Co-rich crusts: A comparative study using the methods of orbital pacing and ${ }^{230} \mathrm{Th}_{\mathrm{ex}} /{ }^{232} \mathrm{Th}$ dating. Sci China Ser D-Earth Sci, 2009, 52: 484-488

Open Access This article is distributed under the terms of the Creative Commons Attribution License which permits any use, distribution, and reproduction in any medium, provided the original author(s) and source are credited. 